Chapman University

Chapman University Digital Commons

Biology, Chemistry, and Environmental Sciences

Science and Technology Faculty Articles and

Faculty Articles and Research

Research

$11-21-2017$

\title{
No Evidence for Trace Metal Limitation on Anaerobic Carbon Mineralization in Three Peatland Soils
}

Jason K. Keller

Jillian Wade

Follow this and additional works at: http://digitalcommons.chapman.edu/sees_articles

Part of the Atmospheric Sciences Commons, Environmental Chemistry Commons, Environmental Monitoring Commons, Organic Chemistry Commons, Other Chemistry Commons, Other Ecology and Evolutionary Biology Commons, Other Environmental Sciences Commons, Other Life Sciences Commons, Other Oceanography and Atmospheric Sciences and Meteorology Commons, and the Terrestrial and Aquatic Ecology Commons 


\title{
No Evidence for Trace Metal Limitation on Anaerobic Carbon Mineralization in Three Peatland Soils
}

\author{
Comments \\ NOTICE: this is the author's version of a work that was accepted for publication in Geoderma. Changes \\ resulting from the publishing process, such as peer review, editing, corrections, structural formatting, and \\ other quality control mechanisms may not be reflected in this document. Changes may have been made to this \\ work since it was submitted for publication. A definitive version was subsequently published in Geoderma, \\ volume 314, in 2018. DOI:10.1016/j.geoderma.2017.11.001 \\ The Creative Commons license below applies only to this version of the article.
}

\section{Creative Commons License}

\section{(c) 1 (1) 90}

This work is licensed under a Creative Commons Attribution-Noncommercial-No Derivative Works 4.0 License.

\section{Copyright}

Elsevier 


\section{No evidence for trace metal limitation on anaerobic carbon mineralization in three peatland soils}

\section{Jason K. Kelle}

jkeller@chapman.edu

\section{Jillian Wade}

Chapman University, Schmid College of Science and Technology, Orange, CA 92866, USA

*Corresponding author

Handling editor: Junhong Bai

\section{Abstract}

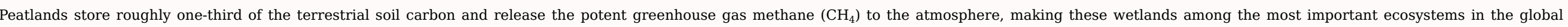

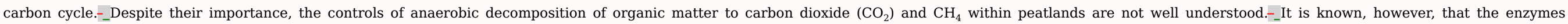

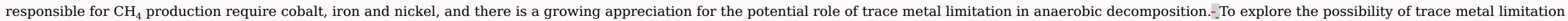

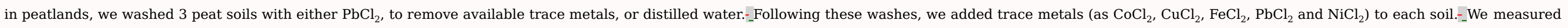

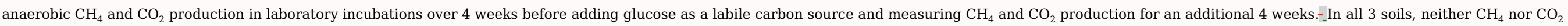

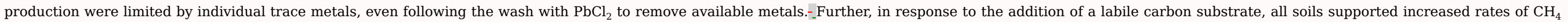
and $\mathrm{CO}_{2}$ production without progressive trace metal limitation.--Taken together, our findings suggest that individual trace metals may not be limiting to anaerobic decomposition in many peatland soils.

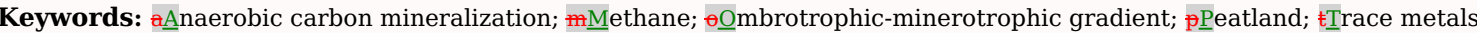

\subsection{Introduction}

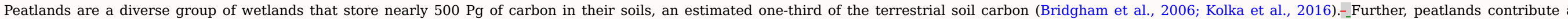

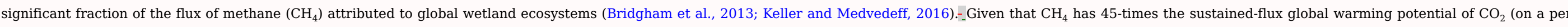

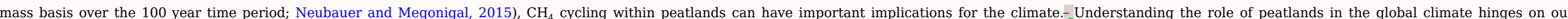
mechanistic understanding of $\mathrm{CH}_{4}$ and $\mathrm{CO}_{2}$ dynamics within peatland ecosystems.

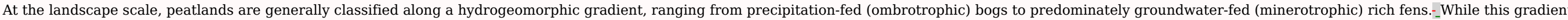

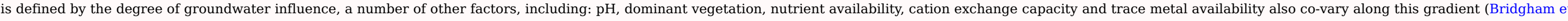

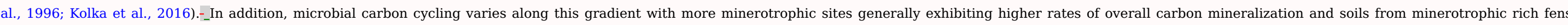

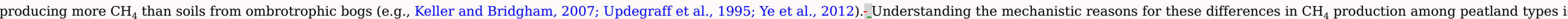
crucial for understanding the potential feedbacks between peatland carbon cycling and global climate change.

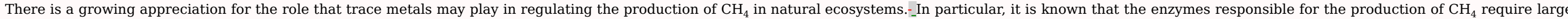

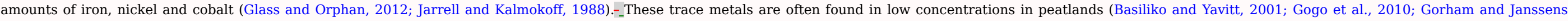

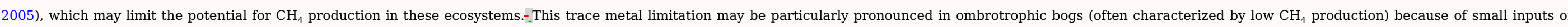

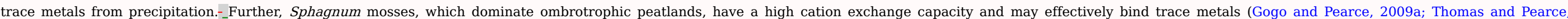




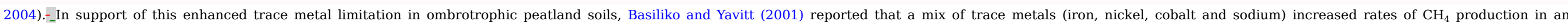

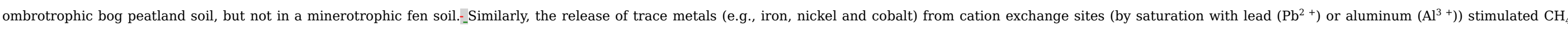
production in a Sphagnum-dominated bog soil, but not in a more minerotrophic fen soil (Gogo and Pearce, 2009b)

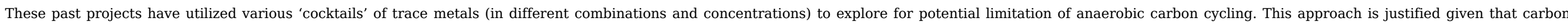

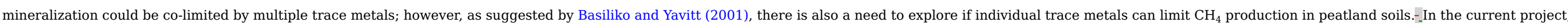

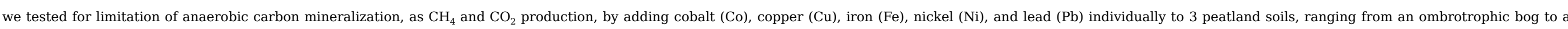

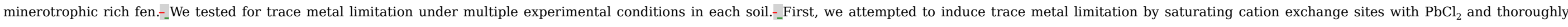

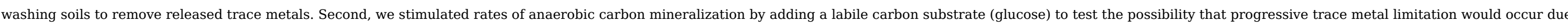

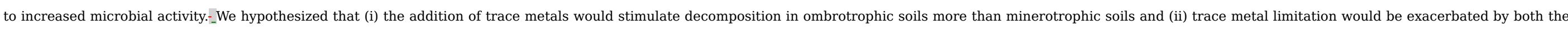
removal of trace metals following the saturation of cation exchange sites as well as by the increased carbon mineralization following the addition of a labile carbon substrate.

\subsection{Materials and methods}

\subsubsection{Site description and sampling}

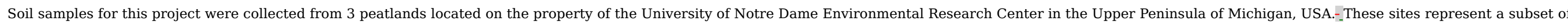

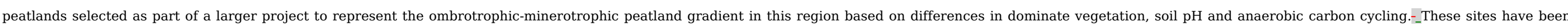
described previously (Ye et al., 2012), and a brief description is provided below.--For consistency, we use the same site names utilized by Ye et al. (2012).

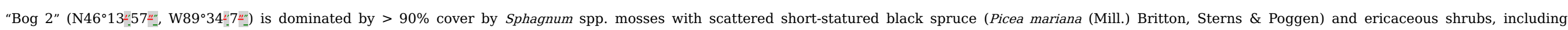

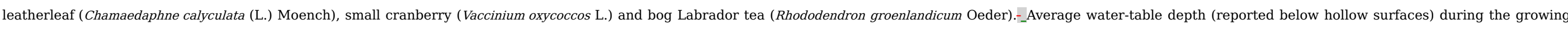

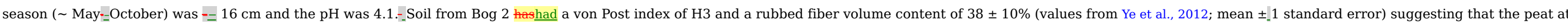

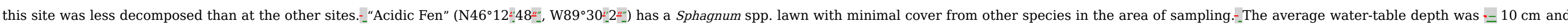

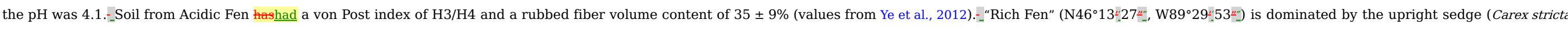

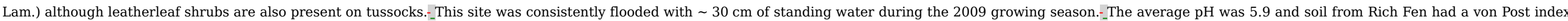
of H5 and a rubbed fiber volume content of $15 \pm 5 \%$ (values from Ye et al., 2012), suggesting that this peat was the most decomposed of the sites studied.

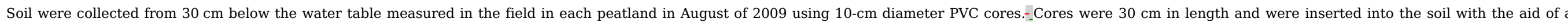

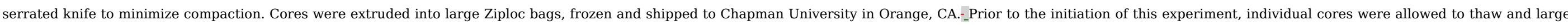
roots and living vegetation were removed by hand in the ambient atmosphere.-_The remaining root-free peat was refrozen.-_The length of time a core was thawed varied, but was generally less than $\leq 1$ week.

\subsubsection{Determination of water-extractable cations and cation exchange capacity}

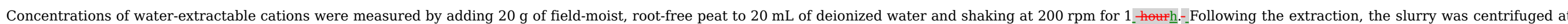

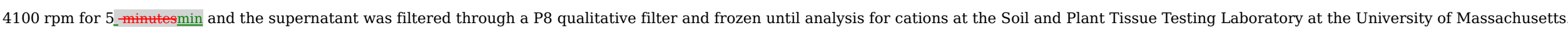

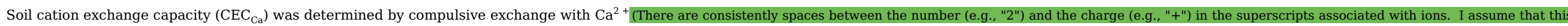

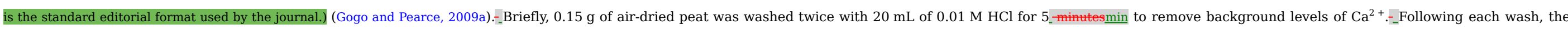

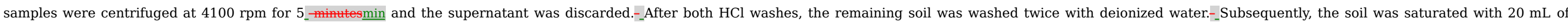

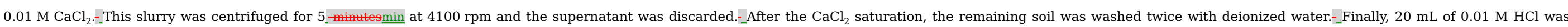

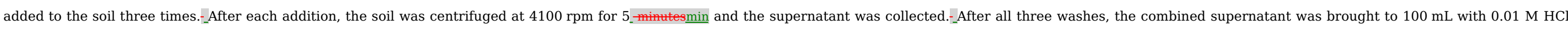
and this solution was analyzed for $\mathrm{Ca}^{2+}$ at the Soil and Plant Tissue Testing Laboratory at the University of Massachusetts. 


\subsubsection{Experimental design}

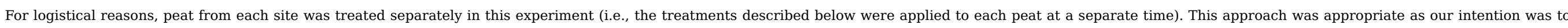
focus on the importance of trace metals on carbon mineralization within a peatland while focusing on the more qualitative patterns (i.e., stimulation or inhibition by a given trace metal) between sites.

\subsection{Wash treatments}

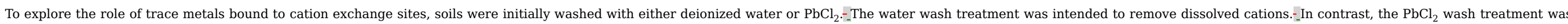

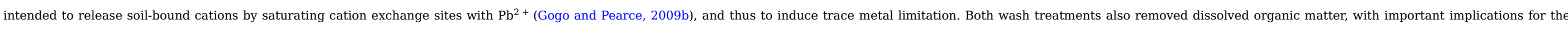

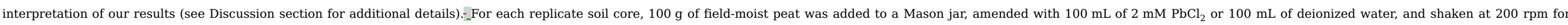

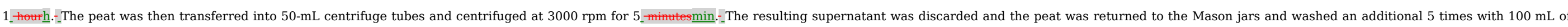

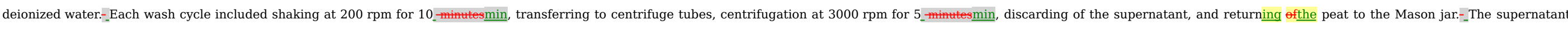

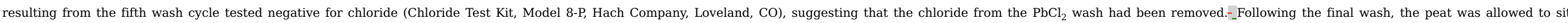
overnight at $4{ }^{\circ} \mathrm{C}$. - The following morning, the peat was centrifuged once more at $3000 \mathrm{rpm}$ for 5 _mintesmin and the supernatant was discarded.

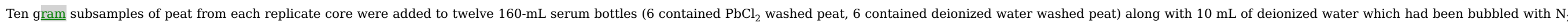

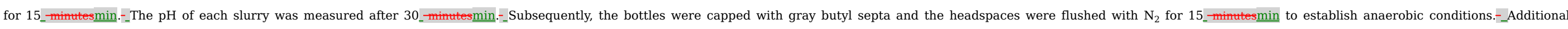
subsamples of washed peat were dried at $60{ }^{\circ} \mathrm{C}$ for 48 -

\subsection{Phase I: equilibration}

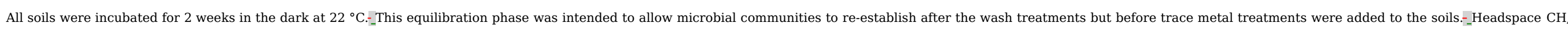

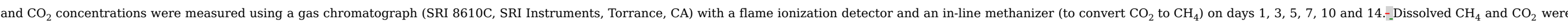
calculated using Henry

\subsection{3-Phase II: trace metal amendment}

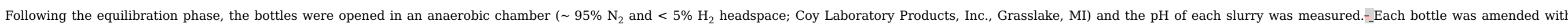

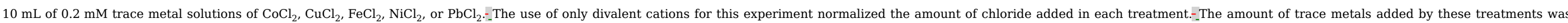

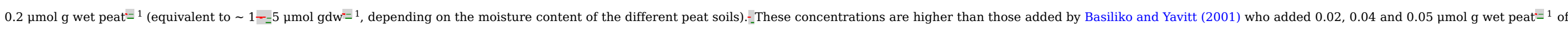

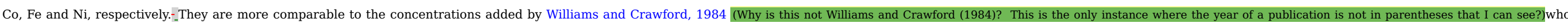

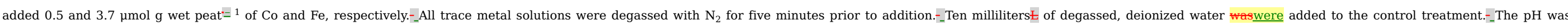

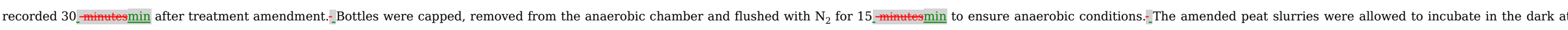
$22{ }^{\circ} \mathrm{C}$ for 4 weeks.- Methane and $\mathrm{CO}_{2}$ production were measured on days 1, 3, 5, 7, 10, 14, 21 and 28 as described above.

\subsection{Phase III: trace metal and labile carbon amendment}

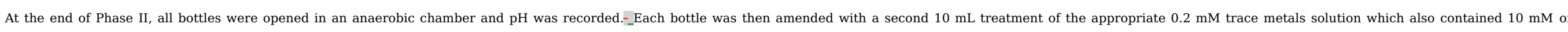

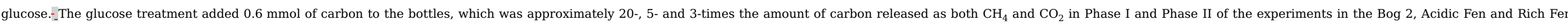

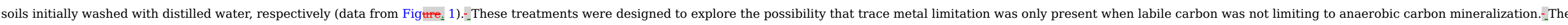

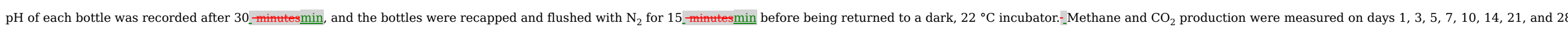
as described above.-_After the final phase of the incubation, the bottles were opened and the final $\mathrm{pH}$ was recorded. 


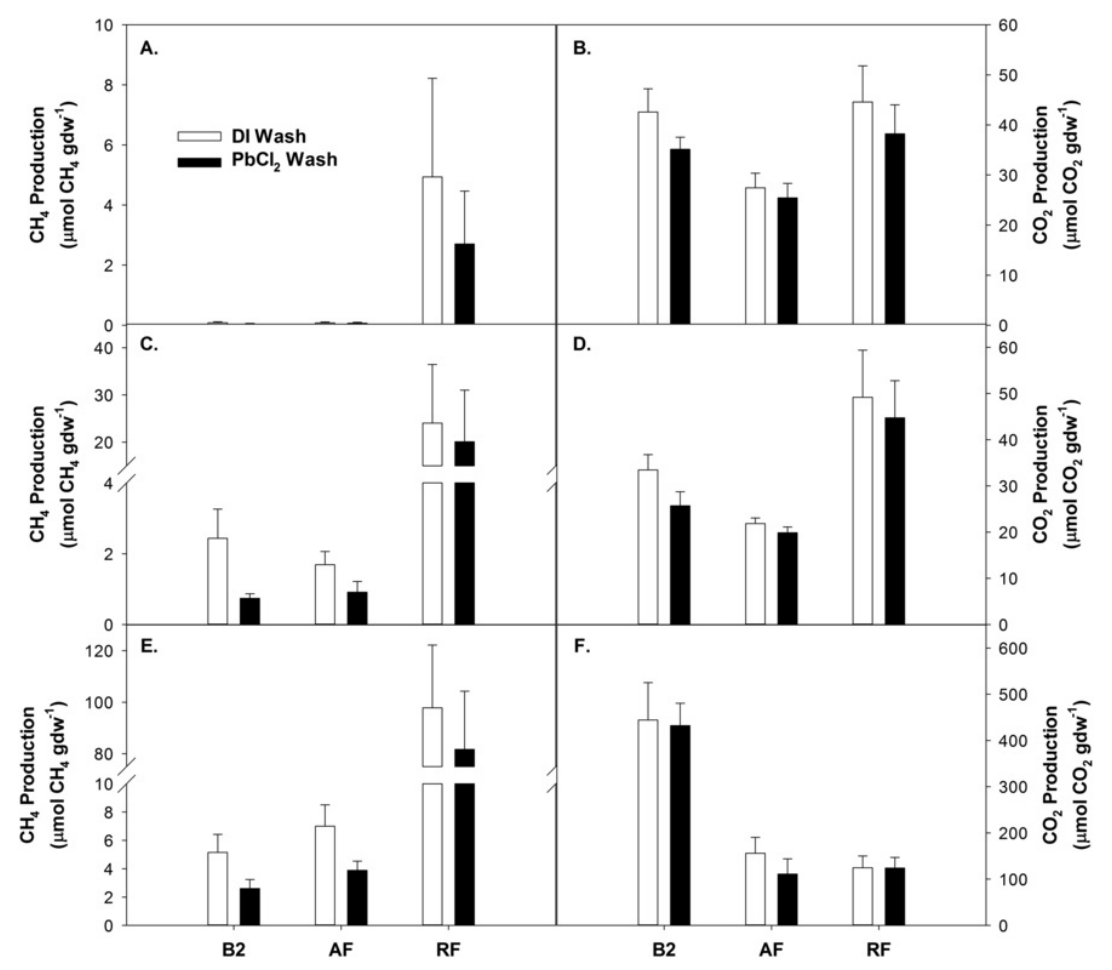

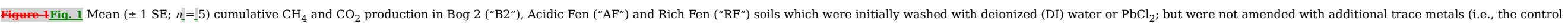

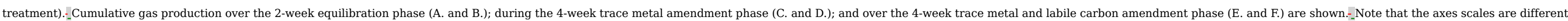
for each panel.

\section{alt-text: Fig. 1}

\subsubsection{Data analysis}

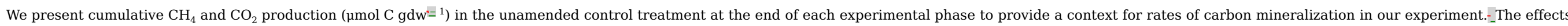

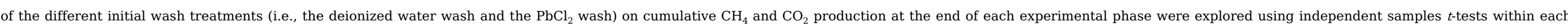

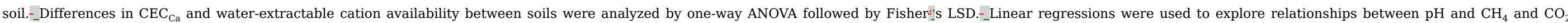
production during an experimental phase.

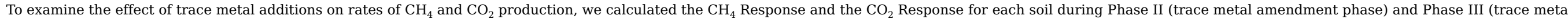
and labile carbon amendment phase) as follows:

Response $=[($ Treatment Rate +1$)-($ Control Rate +1$) /($ Control Rate +1$)] * 100$

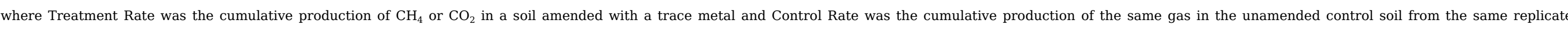

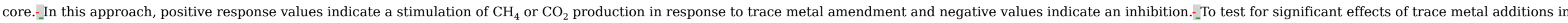

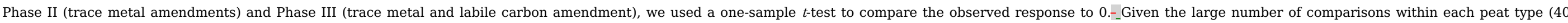
individual tests), we utilized a Bonferroni correction to set $\alpha=0.00125$.- This approach is admittedly conservative, but given the lack of stimulation observed (see below), we felt it was appropriate. 


\subsection{Results}

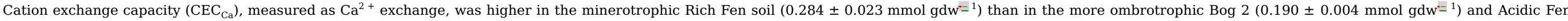

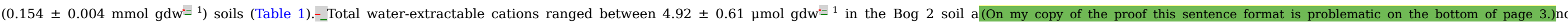

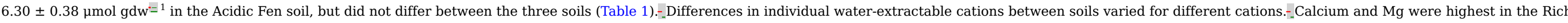
Fen soil; Al was highest in the Acidic Fen soil; $\mathrm{K}$ was lowest in the Rich Fen soil and Fe was lowest in the Bog 2 soil. Water-extractable P was similar in all soils (Table 1).

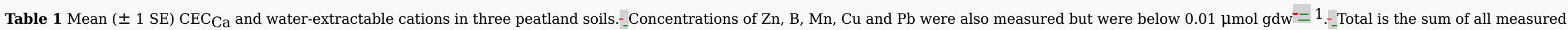
extracted cations.--Different letters reflect differences between the soils $(p<0.05)$ based on one-way ANOVA followed by Fisher's LSD.

\section{alt-text: Table 1}

$\mathrm{CEC}_{\mathrm{C}}$

K

$\mathrm{Mg}$

Total

$\mathrm{mmol} \mathrm{gdw-=1}$

$\mu^{\mathrm{mol} \mathrm{gdw}}=1$

Bog 2

Acidic Fen

$0.190 \pm 0.004^{\mathrm{A}}$

$0.154 \pm 0.004^{\mathrm{A}}$

Rich Fen

$0.76 \pm 0.24$
$0.95 \pm 0.20$
$0.41 \pm 0.14$

$1.04 \pm 0.08^{A}$

$1.14 \pm 0.05^{A}$

$2.84 \pm 0.16$
$0.44 \pm 0.03^{\mathrm{A}}$
$0.49 \pm 0.02^{\mathrm{A}}$
$0.82 \pm 0.07^{\mathrm{B}}$

$0.93 \pm 0.21^{\mathrm{A}}$

$0.10 \pm 0.01^{\mathrm{A}}$
$0.20 \pm 0.04^{\mathrm{B}}$
$0.23 \pm 0.02^{\mathrm{B}}$

$0.40 \pm 0.10^{\mathrm{A}}$
$1.06 \pm 0.13^{\mathrm{B}}$
$0.67 \pm 0.12^{\mathrm{A}}$

$4.92 \pm 0.61$

$6.30 \pm 0.38$

$6.00 \pm 0.57$

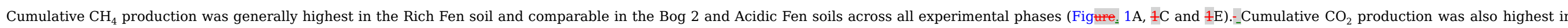

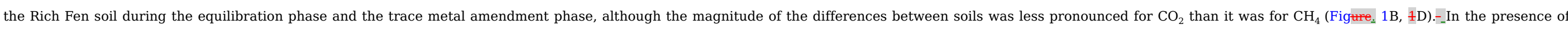
labile carbon, cumulative $\mathrm{CO}_{2}$ production was highest in the Bog 2 soil and comparable between the Acidic Fen and Rich Fen soils (Figure. 1F)

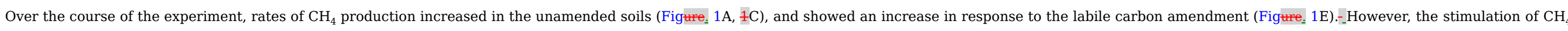

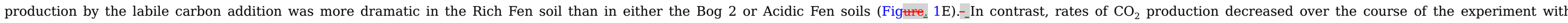

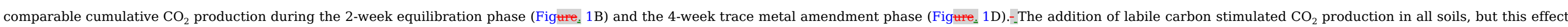
was most pronounced in the Bog 2 soil (Figure. 1F).

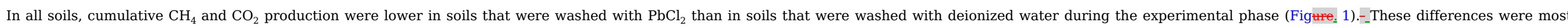

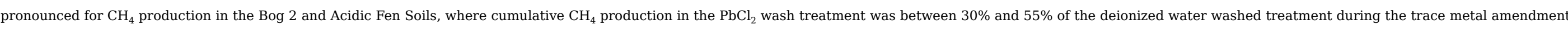

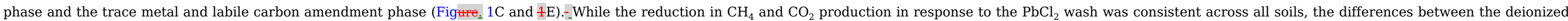
water wash and the $\mathrm{PbCl}_{2}$ wash were not significant in any experimental phase for any soil ( $p \geq 0.08$ for all independent $t$-tests).

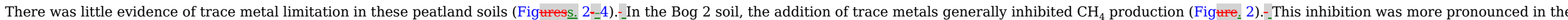

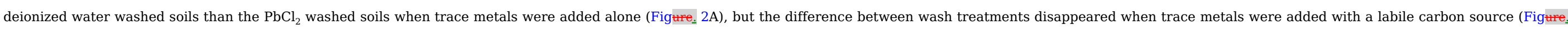

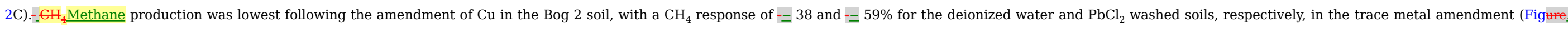

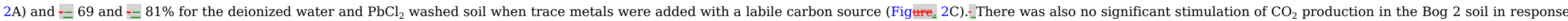

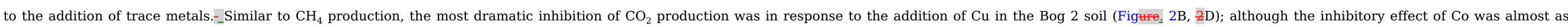
dramatic for the deionized $\underline{\mathrm{PbCl}}_{2}$ washed soil in the absence of labile carbon (Figure. $2 \mathrm{~B}$ ). 


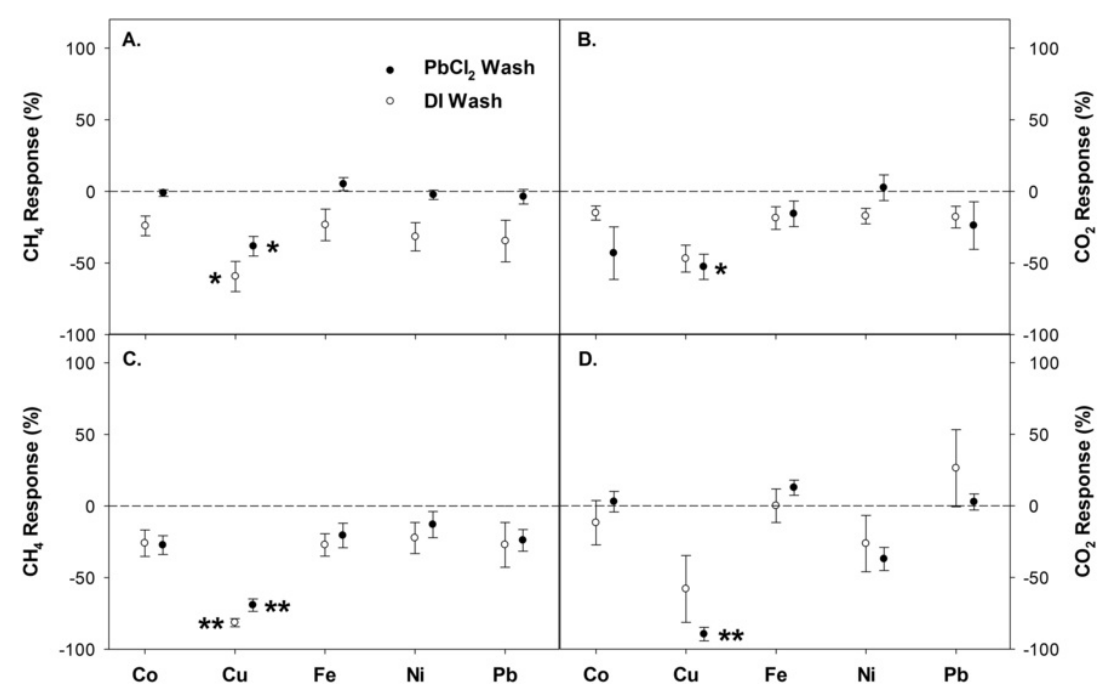

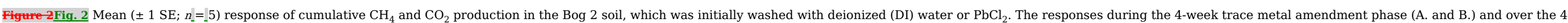

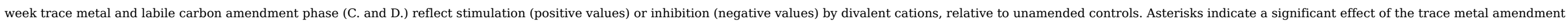
based on a one-sample $t$-test $(*=p \leq 0.005 ; * *=p \leq 0.001)$.

alt-text: Fig. 2

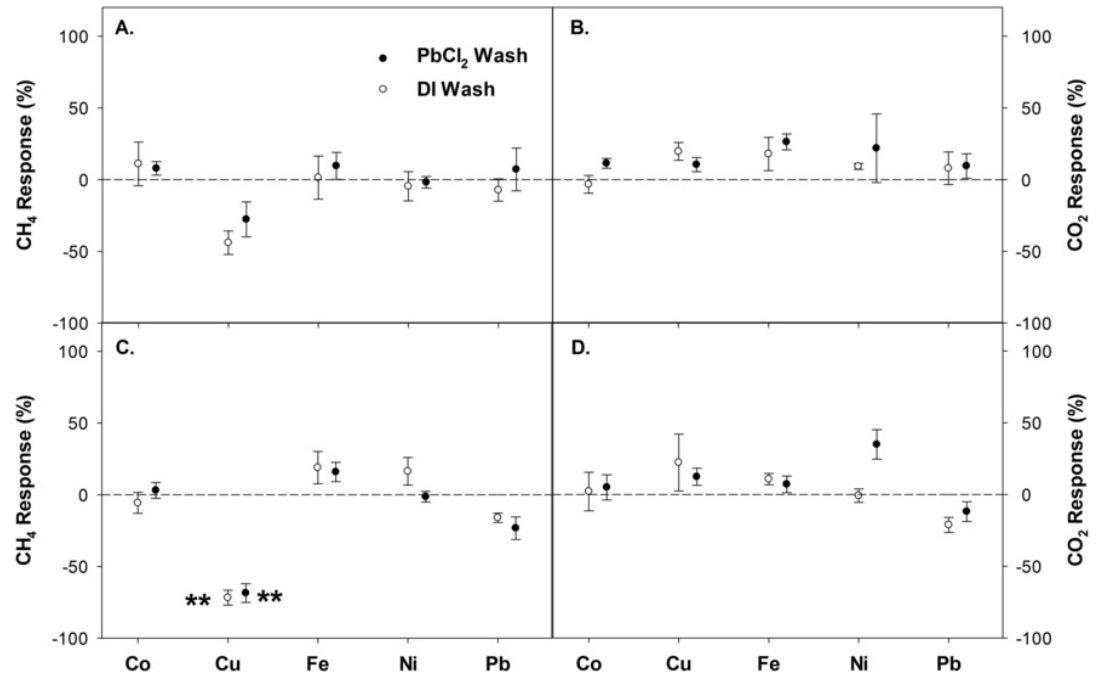

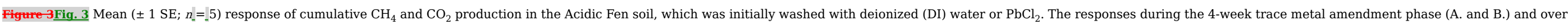

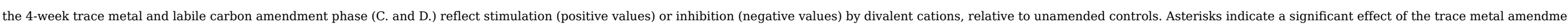
based on a one-sample $t$-test $(*=p \leq 0.005 ; * *=p \leq 0.001)$, 


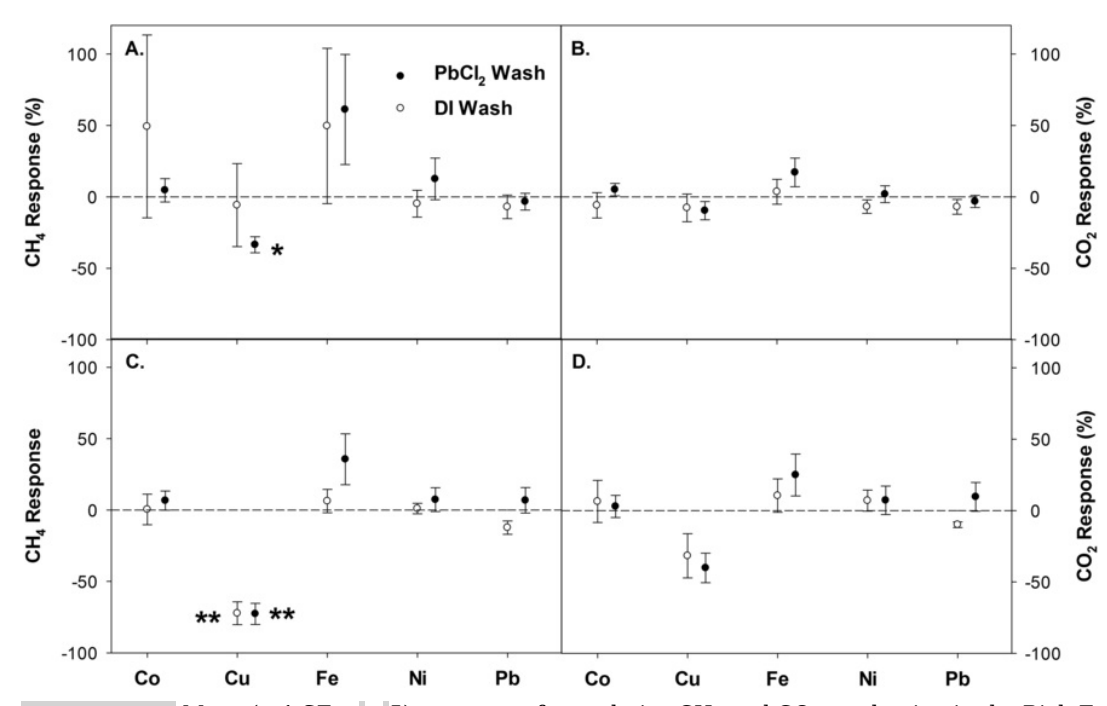

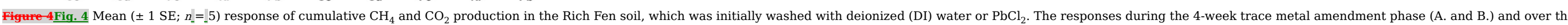

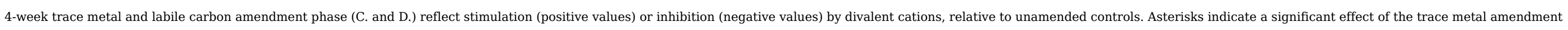
based on a one-sample $t$-test $(*=p \leq 0.005 ; * *=p \leq 0.001)$ alt-text: Fig. 4

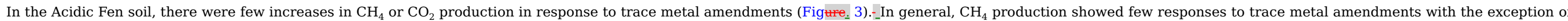

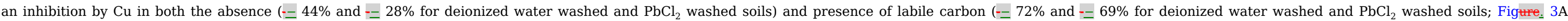

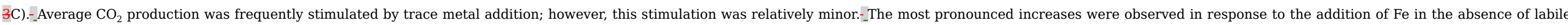
carbon and in response to the addition of $\mathrm{Ni}$ in the presence of labile carbon (Figure. 3B and 3D, respectively).

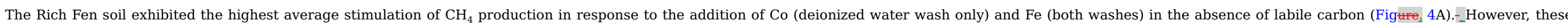

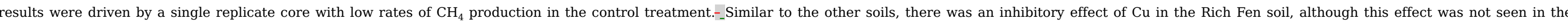

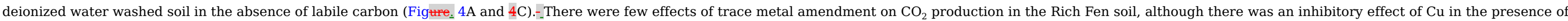
labile carbon (Figure, 4B and 4D).

\section{4. $\underline{4}$ Discussion}

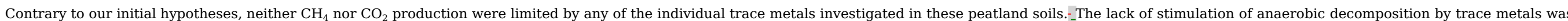

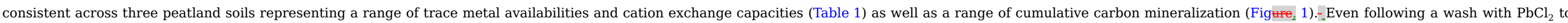

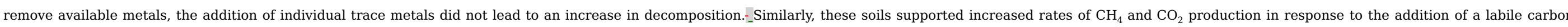
substrate (glucose) without progressive trace metal limitation (Figuress. 2-4).

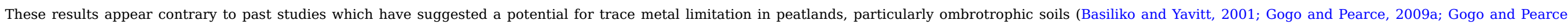

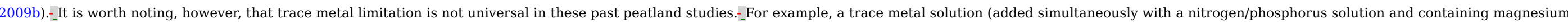

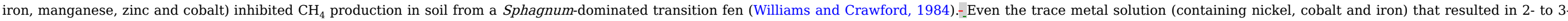

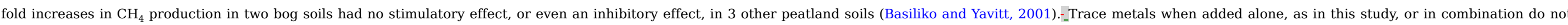
always result in the stimulation of $\mathrm{CH}_{4}$ production in peatlands and the mechanisms for the variable responses in different peats remain elusive. 


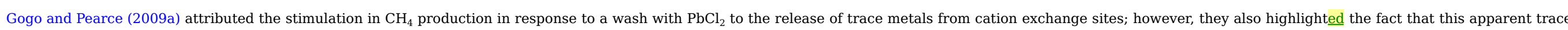

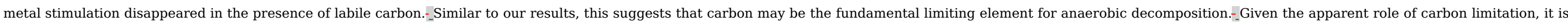

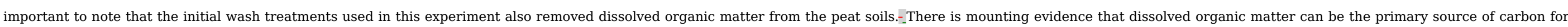

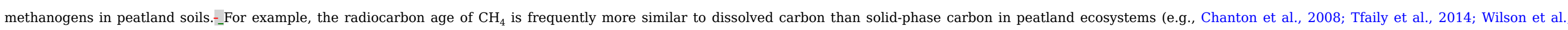

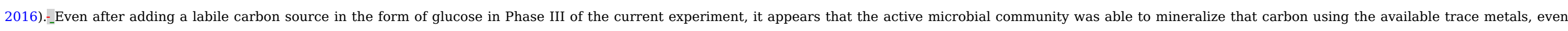
following the $\mathrm{PbCl}_{2}$ wash treatment (Figuress. 2--4).

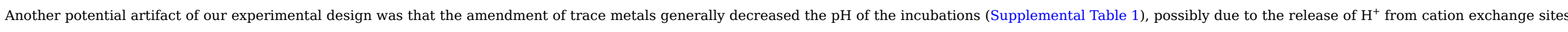

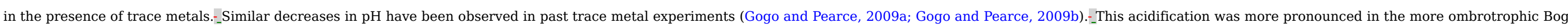

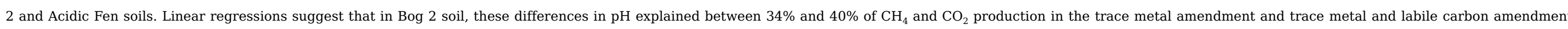

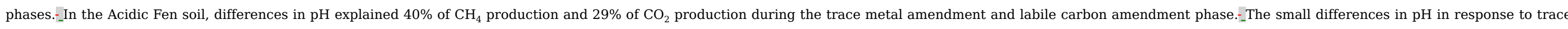

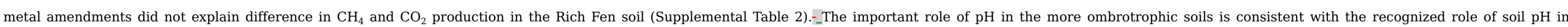

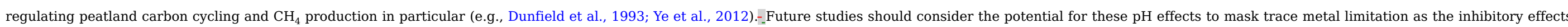
of lower soil $\mathrm{pH}$ would counteract potential stimulation by trace metals.

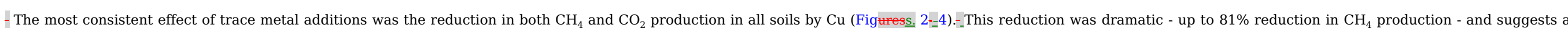

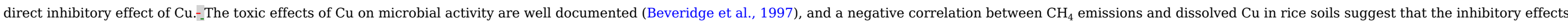

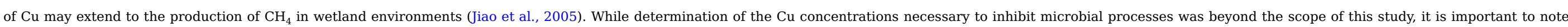

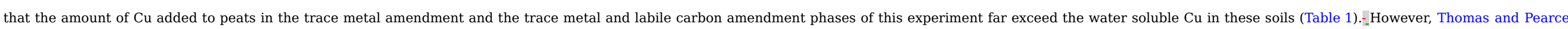

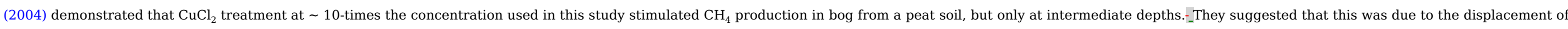
other trace metals coincident with copper binding to CEC sites in this soil.

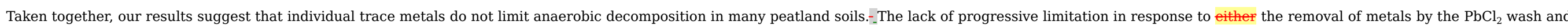
the addition of glucose suggest even increased rates of decomposition are not likely to be limited by trace metals in these systems.

\section{Acknowledgements}

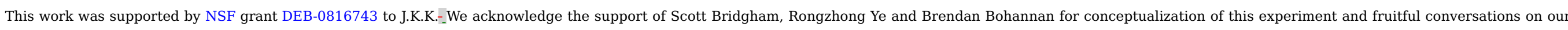

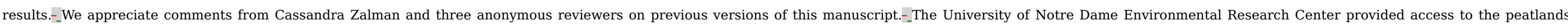
sampled in this study.

\section{Appendix A.Appendix A. Supplementary data}

Supplementary data to this article can be found online at https://doi.org/10.1016/j.geoderma.2017.11.001.

\section{References}

Basiliko N. and Yavitt J.B., Influence of Ni, Co, Fe, and Na additions on methane production in Sphagnum-dominated Northern American peatlands, Biogeochemistry 52, 2001, 133-153.

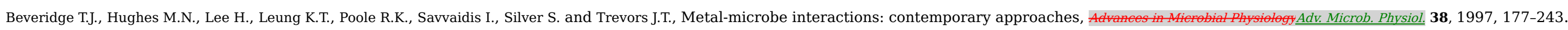

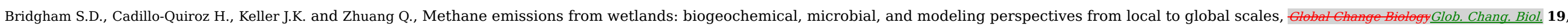

2013, 1325-1346.

Bridgham S.D., Megonigal J.P., Keller J.K., Bliss N.B. and Trettin C., The carbon balance of North American wetlands, Wetlands 26 (4), $2006,889-916$. 
Bridgham S.D., Pastor J., Janssens J., Chapin C. and Malterer T., Multiple limiting gradients in peatlands: a call for a new paradigm, Wetlands 16 (1), $1996,45-65$.

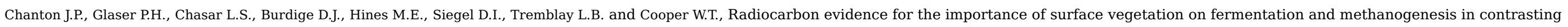
types of boreal peatlands,

Drever J.I., The $\mathfrak{g} \underline{G}$ eochemistry of $n \underline{N}$ atural $¥ \underline{W}$ aters, 3rd ed., 1997, Prentice Hall.

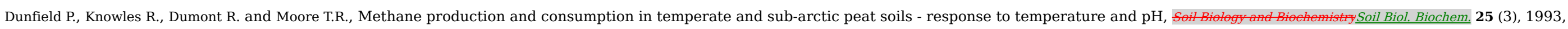
$321-326$.

Glass J.B. and Orphan V.J., Trace metal requirements for microbial enzymes involve in the production and consumption of methane and nitrous oxide, Front. Microbiol. 3, 2012, 1-20.

Gogo S. and Pearce D.M.E., Carbon, cations and CEC: ịnteractions and effects on microbial activity in peat, Geoderma 153, 2009a, 76-86.

Gogo S. and Pearce D.M.E., Saturation of raised bog peat exchange sites by $\mathrm{Pb}^{2+}$ and $\mathrm{Al}^{3+}$ stimulates CH4 production, Soil Biofy \& Bioehemistry Soil Biol. Biochem. 41, 2009b, 2025-2028.

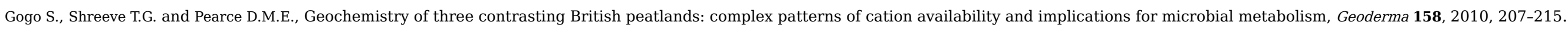

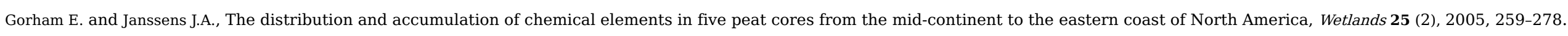

Jarrell K.F. and Kalmokoff M.L., Nutritional requirements of the methanogenic archebacteria, Eanadian Journal of Microbiologj Can. J. Microbiol. 34, 1988, 557-576.

Jiao Y., Huang Y., Zong L., Zheng X. and Sass R.L., Effects of copper concentration on methane emission from rice soils, Chemosphere 58, 2005, 185-193.

Keller J.K. and Bridgham S.D., Pathways of anaerobic carbon cycling across an ombrotrophic-minerotrophic peatland gradient, timnology and OceanographyLimnol. Oceanogr. 52 (1), 2007, 96-107.

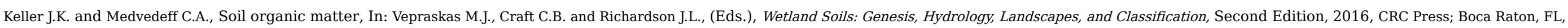
$165-188$.

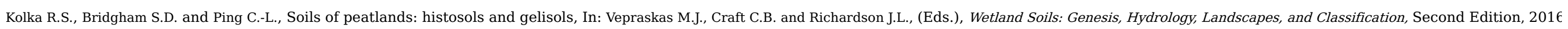
CRC Press; Boca Raton, FL, 277-309.

Neubauer S.C. and Megonigal J.P., Moving beyond global warming potential to quantify the climatic role of ecosystems, Ecosystems 2015, https://doi.org/10.1007/s10021-015-9879-4.

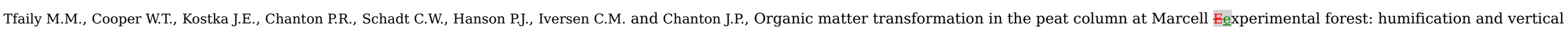
stratification, J. Geophys. Res. Biogeosci. 119, 2014, https://doi.org/10.1002/2013JG002492.

Thomas P.A. and Pearce D.M.E., Role of cation exchange in preventing the decay of anoxic deep peat, Soil Biology \& Biochemisty Soil Biol. Biochem. 36, $2004,23-32$.

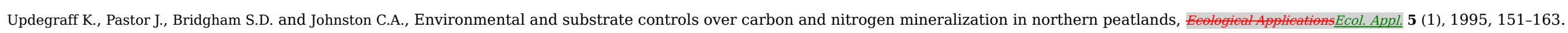

Williams R.T. and Crawford R.L., Methane production in Minnesota peatlands, Applied and Environmental Mierobiology Appl. Environ. Microbiol. 47 (6), $1984,1266-1271$.

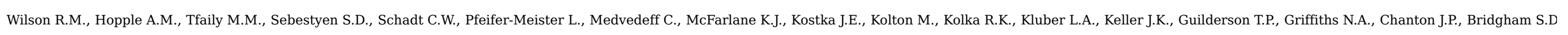
and Hanson P.J., Stability of peatland carbon to rising temperatures, 13723.

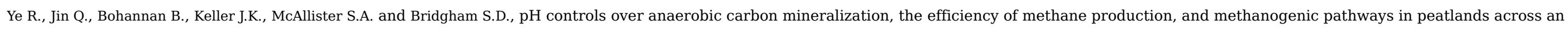
ombrotrophic-minerotrophic gradient, Soil Biology Biochemistry Soil Biol. Biochem. 54, 2012, 36-37.

\section{Appendix A.Appendix A. Supplementary data}




\section{Highlights}

- Carbon cycling within peatlands is important in the context of global climate change.

- There was no evidence of trace metal limitation of anaerobic $\mathrm{CO}_{2}$ and $\mathrm{CH}_{4}$ production in 3 peatland soils

- Addition of copper inhibited anaerobic $\mathrm{CO}_{2}$ and $\mathrm{CH}_{4}$ production in these soils.

\section{Queries and Answers}

Query:

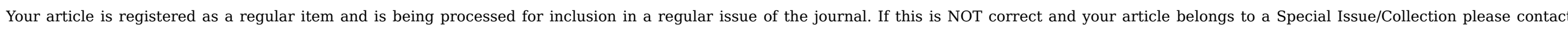
j.raj@elsevier.com immediately prior to returning your corrections.

Answer: This is correct.

Query:

Please confirm that given names and surnames have been identified correctly and are presented in the desired order, and please carefully verify the spelling of all authors' names.

Answer: Both authors are named correctly and in the right order.

Query:

The author names have been tagged as given names and surnames (surnames are highlighted in teal color). Please confirm if they have been identified correctly

Answer: This is correct.

Query:

Supplementary caption was not provided. Please check the suggested data if appropriate, and correct if necessary.

Answer: Calling this "Appendix A. Supplementary data" is appropriate. The link to the supplementary tables is functional and the table formatting matches what we submitted.

Query:

Please provide the volume number and page range for this reference.

Answer: Ecosystems (2015) 18: 1000-1013 (although the recommended citation from the Editor of the journal includes the doi instead of this information). 